\author{
Angelika Szpakowska \\ Uniwersytet w Białymstoku \\ E-MAIL: szpakowskaangelika@gmail.com
}

\title{
Przemoc seksualna wobec dzieci w cyberprzestrzeni
}

\section{STRESZCZENIE}

Internet stworzył nowe możliwości sprawcom nadużyć seksualnych wobec dzieci. Obserwuje się eskalację takich zjawisk, jak uwiedzenia i nadużycia pedofilskie, pornografia i prostytucja dziecięca. Trauma spowodowana przemocą seksualną w dzieciństwie ma poważne konsekwencje w życiu dorosłym. Istotne jest pytanie, jak zapewnić bezpieczeństwo najmłodszym użytkownikom Internetu.

SŁOWA KLUCZOWE: pedofilia, dzieci, Internet

\section{Wstęp}

Anonimowość użytkowników Internetu oraz ogromna liczba przetwarzanych danych stwarza nowe możliwości rozwoju patologicznych aktywności i form działalności przestępczej. Sieć stała się ulubionym miejscem dzieci i młodzieży, w dużej mierze ze względu na częsty brak dozoru rodzicielskiego, możliwości nawiązywania nowych kontaktów i swobodny dostęp do atrakcyjnych lub „zakazanych” treści. Niesie to za sobą ryzyko różnego rodzaju nadużyć ze strony dorosłych internautów. Kampanie informacyjne, takie jak zorganizowana przez Fundację Dajemy Dzieciom Siłę „Chroń dziecko w Sieci”, przestrzegają rodziców przed konsekwencjami kontaktów dzieci ze szkodliwymi treściami w Internecie. Najpoważniejszym zagrożeniem wydaje się przemoc seksualna wobec najmłodszych użytkowników Sieci, do której dochodzi w cyberprzestrzeni.

Celem artykułu jest zwrócenie uwagi osób zaangażowanych w wychowanie i edukację młodego pokolenia na siłę oddziaływania, wielowymiarowość oraz różnorodność przejawów tego zjawiska. Artykuł składa się z trzech części: wprowadzenia, zawierającego wybrane definicje pedofilii, omówienia typowych przejawów nadużyć seksualnych wobec dzieci: prostytucji dziecięcej, cyberpornografii, cyberpedofilii, cyberprostytucji i groomingu, oraz podsumowania, ze wskazaniem na psychospołeczne konsekwencje przemocy seksualnej, prawne środki ochrony dzieci i młodzieży, a także rolę środowiska wychowawczego w profilaktyce i przeciwdziałaniu pedofilii w Internecie. 
Badania Marii Beisert (2012) dowodzą, że źródłem pedofilii są nieprawidłowe doświadczenia seksualne sprawców z okresu dzieciństwa. Seksualizacja dzieci jest efektem zaburzeń $w$ relacji dziecko - rodzic, obcowania z treściami o charakterze seksualnym. Dysfunkcja rodziny w parze ze swobodnym dostępem do Internetu naraża najmłodszych użytkowników Sieci na traumatyzujące doświadczenia, których efektem może być wczesna erotyzacja i rozwój zaburzeń w sferze seksualnej, w tym orientacji pedofilnej. Mamy więc do czynienia z „zaklętym kręgiem” nadużyć. Zapobieganie i przeciwdziałanie narastaniu tego zjawiska w dużej mierze zależy od wiedzy i postaw rodziców i wychowawców, profesjonalnych i adekwatnych programów terapeutycznych dla ofiar i sprawców oraz skuteczności środków ochrony prawnej najmłodszych członków społeczeństwa. Tymczasem rodzice i nauczyciele zazwyczaj nie zdają sobie sprawy z różnorodności form i skali nadużyć seksualnych wobec dzieci, do których dochodzi w Internecie.

W roku 2017 eksperci z zespołu Dyzurnet.pl (komórka Naukowej i Akademickiej Sieci Komputerowej (NASK), która monitoruje i reaguje na pedofilię w Sieci) podjęli 13962 interwencje ws. podejrzanych treści. Co piąta z nich dotyczyła filmów z udziałem dzieci, reszta - zdjęć. Co trzeci taki materiał po interwencji zniknął z Sieci w ciągu dwóch dni. W sumie 2459 spraw zostało zaklasyfikowanych jako materiały przedstawiające seksualne wykorzystywanie dzieci. Po analizie zgłoszenia przekazywane są policji, administratorom stron internetowych lub Interpolowi i stowarzyszeniu INHOPE, które zrzesza podobne zespoły interwencyjne z ponad 50 krajów świata (Wątor, 2018). Zespół Dyzurnet.pl zwraca też uwagę na to, że coraz częściej w Sieci dochodzi do zjawiska zwanego sextortion. Polega ono na pozyskaniu od ofiary materiałów o charakterze seksualnym, a następnie szantażowaniu jej groźbami publikacji zdjęć lub filmów w Sieci. Jej ofiarami bardzo często padają osoby niepełnoletnie.

Szybko rozprzestrzeniającą się nową formą pedofilii jest internetowa turystyka seksualna. Siedząc w swoim domu, sprawcy, dzięki kamerom, obserwują na żywo gwałt dokonywany na dzieciach w innym kraju, najczęściej w jednym z biednych państw Azji Południowej. Mają ponadto możliwość wydawania poleceń osobom biorącym udział w gwałcie (DW, J.K., 2018). Skala tego zjawiska jest bardzo trudna do oszacowania. Globalna wioska nie jest bezpiecznym miejscem dla małych dzieci.

\section{Definicje pedofilii}

W literaturze przedmiotu obok „przemocy seksualnej wobec dzieci” stosuje się zamiennie takie terminy, jak: „wykorzystywanie seksualne”, „krzyw- 
dzenie seksualne”, „molestowanie seksualne” czy też „nadużycie seksualne”. Światowa Organizacja Zdrowia proponuje używanie terminu "przemoc seksualna”, przez którą rozumie się wykorzystywanie dzieci w celu uzyskania satysfakcji seksualnej przez osoby dorosłe (Kluczyńska, 2002).

W znaczeniu klinicznym termin „pedofilia” odnosi się do „wewnętrznej, psychicznej dyspozycji człowieka, zwykle przejawiającej się w jego zachowaniu, oznacza zjawisko z obszaru psychopatologii (Beisert, 2012, s. 19-20). Istnieje wiele, zbliżonych treściowo, klinicznych definicji pedofilii, mających charakter autorski. Zaprezentuję niektóre $\mathrm{z}$ nich. Kazimierz Imieliński: „Pedofilia [...] jest odchyleniem seksualnym, przejawiającym się w skłonności do praktyk seksualnych z dziećmi" (1990, s. 193). Zbigniew Lew-Starowicz: „Pedofilia [...] jest to [...] parafilia, polegająca na osiąganiu satysfakcji seksualnej w kontaktach z dziećmi” (2000, s. 127). Robert C. Carson: „Pedofilia - to parafilia, w której preferowanym lub wyłącznym partnerem seksualnym osoby dorosłej jest dziecko przed okresem pokwitania” (2003, s. 653). Kazimierz Pospiszyl: „Pedofilia - zaburzenie preferencji seksualnej, przejawiające się tym, że cel (obiekt) pożądania seksualnego stanowi dziecko, niewykazujące jeszcze cech dojrzewania płciowego" (2005, s. 307). Irena Pospiszyl: "Pedofilia jest terminem medycznym, określającym, mówiąc najogólniej, seksualny popęd osoby powyżej wieku dziecięcego, skierowany na dziecko" (2008, s. 245). Kurt Freund: „[...]utrzymująca się erotyczna skłonność (preferencje) do dzieci w wieku do lat 11 lub 12 włącznie, większa niż do ludzi dojrzałych fizycznie, przy swobodnym wyborze partnera" (1981, s. 140).

Kluczowym elementem $w$ definiowaniu pedofilii jest określenie definicji dziecka. Badacze problemu pokazują, że przy odróżnianiu pedofilów od niepedofilów naturalną granicą dzieciństwa jest granica biologiczna, wyznaczona przez zmiany wyglądu związane z dojrzewaniem. Z punktu widzenia biologii dzieckiem jest osoba $\mathrm{w}$ wieku przedpokwitaniowym (brak oznak dojrzewania). Według ustaleń badaczy preferowanym przez pedofila obiektem pożądania jest właśnie dziecko przed okresem dojrzewania. Czynnikiem decydującym jest brak wtórnych cech płciowych, a nie konkretny wiek. Richard Green zaproponował jako granicę biologiczną dzieciństwa drugie stadium skali Tannera (czyli: piersi nieznacznie uwypuklone, brodawka sutkowa jest powiększona, w okolicy łonowej pojawiają się pierwsze włosy) (Tanner i Davies, 1985, s. 107). Jednak niektórzy badacze wskazują również konkretne granice wiekowe, np. Freund w swoich pracach zastosował granicę wieku 12 lat, a w definicji zawartej w systemie DSM jest podana orientacyjna granica wieku - 13 lat. W wersji klasyfikacji ICD-10 rozszerzono zakres pojęcia „dziecko” na osoby we wczesnym wieku pokwitaniowym (early pubertal age). 
Zalecenia diagnostyczne, które są zawarte w opisie pedofilii w różnych klasyfikacjach, tj. DSM oraz określenie pedofilii w ICD, umożliwiają wyróżnienie trzech kategorii pedofilii: 1) homoseksualnej, 2) heteroseksualnej, 3) biseksualnej. Natomiast w niektórych przypadkach uważa się, iż płeć dziecka nie ma większego znaczenia dla pedofila, gdyż niedojrzałe ciało dziecka, niezależnie od jego płci, jest w pedofilii rodzajem fetyszu, a nie jest czynnikiem samowystarczalnym (Freund, 1981, s. 139-179; 1990).

\section{Prostytucja dziecięca}

Pedofilia może prowadzić do najbardziej drastycznego naruszenia praw człowieka, czego szczególnym przykładem jest prostytucja dziecięca. W ciągu ostatnich lat doszło do nasilenia się tych zjawisk. Czynnikami warunkującymi wzrost popytu na wykorzystanie najmłodszych do wyżej wymienionych celów są: strona ekonomiczna (z jednej perspektywy zysk, z drugiej ubóstwo), rozwój technologii (Internet), turystyka światowa, zmiany w obyczajowości (sponsoring, sugar babies). Mimo różnorodnych działań podejmowanych przez państwa i organizacje międzynarodowe nie udaje się skutecznie przeciwdziałać prostytucji i pornografii dziecięcej. Pornografia i prostytucja dziecięca stanowi znaczące źródło dochodu grup przestępczych zorganizowanych, działających na arenie międzynarodowej. Wyróżnia się trzy formy prostytucji dziecięcej: handel usługami seksualnymi na szeroką skalę, wykorzystywanie dziecka $\mathrm{w}$ najbliższym otoczeniu oraz dobrowolną prostytucję (różnego rodzaju formy zarobkowania, usługi seksualne w zamian za towary luksusowe; nie zawsze jest to spowodowane nędzą czy ubóstwem, niekiedy wynika $\mathrm{z}$ tendencji do wygodnego życia lub chęci posiadania).

Prostytucję dziecięcą definiuje się jako „świadczenie usług seksualnych przez osoby niepełnoletnie osobom dorosłym $\mathrm{w}$ zamian za pieniądze lub inne korzyści jak jedzenie, schronienie" (Lim, 1998). Brunon Hołyst (2007) definiuje ją jako „angażowanie dziecka lub oferowanie jego usług seksualnych danej osobie za korzyści finansowe lub innego rodzaju wynagrodzenie”. Termin „prostytucja dziecięca” określa wykorzystanie dzieci w czynnościach seksualnych za zapłatą lub inną formą wynagrodzenia. Prostytucja jest zjawiskiem bardzo dynamicznym, dostosowującym się nie tylko do rynku, ale również do zmian społecznych, przez co stale powstają jej nowe formy, co zostanie szerzej omówione w dalszej części.

W literaturze przedmiotu znajdziemy opis trzech typów kręgów rozróżnianych pod względem ilości zaangażowanych osób dorosłych, jak również sposobów wykorzystywania dzieci: krąg pojedynczy (the solo ring) składa się na ogół z jednej osoby dorosłej, która angażuje się w działalność seksualną 
z małą grupą dzieci, a materiały dokumentujące nadużycia w postaci zdjęć i nagrań przeważnie nie są dalej przekazywane. Dorosły, który jest „organizatorem” takiego kręgu, nie udostępnia także „swoich” dzieci innym osobom. Krąg pośredni (the transitional ring): w tych kręgach działa od jednej do kilku dorosłych osób, związanych zwykle z kilkorgiem dzieci, brak tu jednak aspektu organizacyjnego. Taki krąg może z czasem przekształcić się w syndykaty. Syndykat (the syndicated ring) obejmuje zazwyczaj kilka osób dorosłych, ktore tworzą dobrze ustrukturalizowaną organizację, zajmując się rekrutacją dzieci, jak również produkcją pornografii, świadczeniem usług seksualnych z wykorzystaniem dzieci oraz tworzeniem sieci klientów (Burgess i Hartman, 1987, s. 248-253). Odbywa się to za pośrednictwem Internetu.

\title{
W Sieci: cyberpornografia, cyberpedofilia, cyberprostytucja i grooming
}

$\mathrm{W}$ czasach intensywnego rozwoju technologii informacyjnej i nowych sposobów komunikacji mamy do czynienia z cyberprzestępczością, która bardzo często dotyka dzieci (choć nie tylko). W dobie zaawansowanych sposobów cybernetycznego poszukiwania, porządkowania i wykorzystywania informacji Internet staje się swoistym terenem łowieckim, dającym nowe możliwości zaspokajania dewiacyjnych skłonności. Ze względu na brak bezpośredniego kontaktu dziecko poszukujące w Sieci nowych przyjaciól, zainteresowania i zrozumienia, łatwo może paść ofiarą groomingu, czyli uwiedzenia.

\begin{abstract}
Internet ze względu na interaktywność, anonimowość i globalny charakter jest idealnym nośnikiem wzorów zachowań wszelkich grup marginalnych społecznie, w tym pedofilów. Stanowi miejsce nawiązywania przez nich kontaktów, wymiany zdjęć i filmów pornograficznych $\mathrm{z}$ udziałem dzieci oraz informacji na temat ich. Jest wykorzystywany do zawierania znajomości z dziećmi, ich uwodzenia i umawiania się z nimi na spotkanie [...]. Odgrywa rolę kanału przerzutowego materiałów fotograficznych stanowiących plon wycieczek seksturystów z Europy lub USA na Daleki Wschód [...]. Umożliwia dostęp do tysięcy komercyjnych serwerów oferujących pornografię dziecięcą [...]. Tworzy infrastrukturę technologiczną dla kół, grup dyskusyjnych i klubów pedofilów [...]. Integruje tym samym ich środowisko i nadaje mu cechy międzynarodowej podkultury obejmującej także polskich użytkowników Sieci (Adamski, 2003, s. 60).
\end{abstract}

\section{Cyberpornografia}

Cyberpornografia jest zjawiskiem nowym i budzącym liczne kontrowersje. Głównym problemem jest sposób jej generowania poprzez systemy i programy komputerowe. Często postać dziecięca w produkcjach o zdecydowanie pornograficznym charakterze jest wytworem programu komputerowego. Zwolennicy tego typu filmów oświadczają, że „nie ma dzieci, nie ma przestępstwa”. 
Jest zamysł artystyczny i filmowa fikcja - zupełnie tak samo jak w filmach fantasy. Sceny gwałtów na dzieciach są porównywane $\mathrm{z}$ „udawanym morderstwem. Na filmie nikt nikogo nie zabija" (Waglowski, 2002). W tym wypadku mamy do czynienia z postępem technologicznym, który umożliwia realizację sekwencji video bez udziału żywych dzieci w sposób cyfrowy. Już nie jest to typowe "fizyczne wykorzystywanie" dziecka. Nie zmienia to postrzegania dzieci w sposób przedmiotowy, instrumentalny. A co gorsza, sam fakt wykorzystywania seksualnego dziecka staje się „czymś normalnym” (Jędrzejczak, 2007). Istnieje ryzyko przeniesienia tej fikcji do świata realnego.

\section{Cyberpedofilia}

Cyberpedofilia odkrywa nowe oblicze osób o skłonnościach pedofilskich. Zbigniew Lew-Starowicz uważa, iż cyberpedofile swoim potencjalnym ofiarom pokazują się jako: jawni, niekryjący się ze swoimi preferencjami seksualnymi; pedofile dziecięcy, czyli udający dzieci; „auto pedofile”, którzy pragną być traktowani jak dziecko (Lew-Starowicz, 2003, s. 207). Cyberpedofile, oprócz nieprawidłowo ukierunkowanego popędu seksualnego czy niedojrzałości emocjonalnej, wykazują też znacznie większą od przeciętnego użytkownika Internetu skłonność do konfabulacji i autokreacji. Ponadto cyberpedofilia przejawia się różnymi działaniami, takimi jak: tworzenie stron WWW skłaniających do zalegalizowania pedofilii, wyszukiwanie potencjalnych ofiar za pomocą komunikatorów, czatów, poczty elektronicznej, wciąganie dzieci w rozmowy mające kontekst seksualny.

Anonimowość sprzyja poczuciu bezkarności pedofila, co ośmiela go do wykonywania czynności, na które nie miałby odwagi w realnym świecie, ze względu na niską dojrzałość emocjonalną czy trudności w nawiązywaniu kontaktów (Andrzejewska i Bednarek, 2014, s. 142). Jak zauważa John Carr, cyberpedofilom

Sieć umożliwia [...] szybsze, bezpieczniejsze i bardziej przystępne niż w realnym świecie nawiązywanie kontaktów z innymi pedofilami oraz wymianę posiadanych doświadczeń. W trakcie pierwszych rozmów z dzieckiem pedofil często stara się ustalić dokładną lokalizację komputera w domu ofiary. Próbuje się dowiedzieć, z jakim prawdopodobieństwem któryś z domowników mógłby przypadkowo zobaczyć lub usłyszeć jego rozmowy z potencjalną ofiarą. Często stara się nakłonić dziecko, żeby usuwało z komputera wszelkie ślady ich kontaktów, ponieważ [...] zapis takich rozmów mógłby dostarczyć policji użytecznego materiału dowodowego" (za: Andrzejewska i Bednarek, 2004, s. 143). 


\section{Cyberprostytucja}

Zjawisko to polega na uzyskiwaniu korzyści materialnych w zamian za udostępnianie, przekazywanie $\mathrm{w}$ Internecie materiałów erotycznych lub pornograficznych z udziałem dzieci lub dorosłych. Są to: zdjęcia, filmy, transmisje na żywo za pomocą kamerek internetowych. Istnieją wyspecjalizowane serwisy umożliwiające nawiązywanie takich połączeń i transmisji na żywo. Przekazy te mogą zostać nagrane przez odbiorców, a w późniejszym etapie udostępniane w Internecie. Osoby, które oferują materiały, otrzymują wynagrodzenie w formie przelewów finansowych, doładowania konta, karty prepaid, kodów rabatowych itp. Osoby prostytuujące się mogą to robić dobrowolnie lub pod przymusem. Wirtualna prostytucja jest atrakcyjną formą zarobkową dla wielu osób we wszystkich kategoriach wiekowych. Jednak bardzo często angażują się w nią osoby niepełonoletnie. Materiały wytworzone przez dzieci z ich własnej woli, jak i pod przymusem, często są poszukiwane przez osoby o pedofilskich skłonnościach i wykorzystywane nie tylko do celów zaspokojenia własnych dewiacyjnych potrzeb, ale również do zachęcania innych dzieci, aby uczestniczyły $\mathrm{w}$ tego typu nagraniach, zdjęciach lub do odbycia stosunku płciowego $\mathrm{z}$ dorosłym (Polak, Różycka, Marańda i Szeląg, 2013, s. 6).

\section{Grooming}

Grooming to pojęcie pochodzące sprzed epoki Internetu. W realnym świecie sprawca systematycznie oswajał ofiarę ze swoją obecnością, starając się zdobyć zaufanie dziecka, aby przygotować je do kontaktu seksualnego. Budował przyjacielską relację poprzez rozmowy, wspólną zabawę, wręczanie prezentów. Głównym problemem była różnica wieku między ofiarą a sprawcą, co utrudniało nie tylko zdobycie zaufania dziecka, ale również nawiązanie z nim intymnego kontaktu, głównie ze względu na kontrolę rodziców. Jednak aby nie wzbudzać podejrzeń, sprawcy obserwowali dzieci w pobliżu miejsc, gdzie mogły one pozostawać bez nadzoru dorosłych opiekunów. Często również wybierali inne rozwiązanie - stawali się przyjaciółmi rodziny, aby mieć możliwość uwodzić najmłodszych w pobliżu niczego niepodejrzewających rodziców. Proces groomingu offline wymagał od sprawcy z reguły wielkiego zaangażowania, ale również przebiegłości, sprytu i stosowania odpowiednich technik na każdym etapie nawiązania relacji z ofiarą. $\mathrm{W}$ drugiej połowie $\mathrm{XX}$ wieku sprawcy zaczęli się stopniowo przenosić ze świata rzeczywistego $\mathrm{w}$ dużo bezpieczniejsze dla nich rejony Internetu. Wirtualna rzeczywistość stwarzała bowiem o wiele większe możliwości w budowaniu tego typu więzi oraz manifestowania zachowań seksualnych, niemożliwych w świecie realnym (Dąbrowska, 2018, s. 13-15). 


\section{Podsumowanie. Bezpieczeństwo dziecka}

Monika Sajkowska wskazuje w swoich badaniach przemoc seksualną wobec dzieci jako najbardziej raniący rodzaj przemocy, który pozostawia głęboki ślad w psychice i niesie za sobą wiele konsekwencji w dorosłym życiu. Dotyka ona wszystkich sfer życia człowieka: fizycznej, psychicznej i duchowej. W przypadku gdy sprawcą jest osoba bliska, cierpienie dziecka stale rośnie i staje się coraz dotkliwsze z powodu ciągłego poczucia strachu, poniżenia, wstydu, winy. Ponadto dziecko jest zmuszane do utrzymania tajemnicy, co potęguje poczucie samotności, opuszczenia oraz lęku (Sajkowska, 2002). James Beverly opisał, jak zróżnicowane i liczne mogą być dla dziecka następstwa psychologiczne traumy wykorzystywania seksualnego utrzymujące się także w dorosłym życiu. Zaliczył do nich:

1) poczucie winy (kształtowane przez sprawcę, który najczęściej przypisuje dziecku winę, żeby oczyścić siebie, ale także kreowane przez samo dziecko; przez przejęcie odpowiedzialności dziecko może nadal żywić wobec sprawcy przyjazne uczucia, jak również mieć złudną nadzieję, iż to ono kontroluje sytuację). Dziecięce ofiary przemocy seksualnej jako dorośli izolują się od innych, wymierzają sobie karę za to, co wydarzyło się w przeszłości, poprzez np.: samookaleczenia, próby samobójcze, deprecjację własnych osiągnięć, uzależnienia;

2) poczucie bezsilności (sprawca najczęściej nakłada na dziecko obowiązek milczenia, utwierdza dziecko, że nic i nikt nie może mu pomóc, na skutek czego pozostaje ono samo ze swoim strachem; w dorosłym życiu uczucie to wywołuje wycofanie z życia, ewentualnie nadmierne kontrolowanie wszystkiego);

3) poczucie osamotnienia (zranienie przez najbliższych powoduje utratę zaufania oraz wycofywanie emocji, co u osoby dorosłej objawia się depresją, problemami psychosomatycznymi, powodując np.: chroniczne bóle, napięcia mięśniowe, zaburzenia oddechowe, jak również unikanie bliskiego kontaktu, niepokój);

4) stygmatyzację (czyli przekonanie, że wszyscy wiedzą, że jest się kimś gorszym z powodu tego, co się stało, stąd późniejsze stosowanie środków psychoaktywnych, zachowania autodestrukcyjne, ryzykowne sporty, samookaleczenia, próby samobójcze);

5) erotyzację: dziecko wykorzystywane seksualnie dostało od dorosłego fałszywe informacje na temat moralności i zachowań seksualnych, zaczyna postrzegać siebie wyłącznie jako obiekt seksualny (Beverly, 2003). 
Zdaniem Magdaleny Kobyłeckiej (2009) terapia dzieci - ofiar traumy jest nadal otwartym polem dla badaczy i terapeutów. Głównym elementem, na którym skupiają się oddziaływania terapeutyczne, są objawy pojawiające się po wykorzystaniu, takie jak: nieadekwatne do wieku zachowania seksualne, zaburzenia snu, zachowania agresywne. Jest wiele technik wywodzących się głównie $\mathrm{z}$ terapii behawioralno-poznawczej, które wykorzystywane są $\mathrm{w}$ pracy $\mathrm{z}$ wyżej wymienionymi objawami. Badaczka zwraca uwagę na inny ważny czynnik, który pomaga dzieciom wrócić do równowagi i wpływa na ich rozwój - relację. Zarówno relację terapeutyczną, ale i inne relacje dziecka z ważnymi dla niego dorosłymi. Relacja jest procesem, który wymaga emocjonalnego zaangażowania stron; warunkiem jej rozwoju jest odzyskanie przez dziecko zaufania do osób dorosłych. Ochrona i troska o dobro najmłodszych członków społeczeństwa jest wspólnym obowiązkiem dorosłych, co wyraża idea hasła: „Wszystkie dzieci są nasze”.

W Polsce istnieje wiele aktów prawnych dotyczących ochrony dzieci. Najważniejszym z nich jest Konstytucja Rzeczypospolitej Polskiej z dnia 2 kwietnia 1997 r., która w art. 72 przewiduje ochronę dziecka, przed przemocą, wyzyskiwaniem i demoralizacją. Inne to: Konwencja o prawach dziecka przyjęta w 1989 r. przez Zgromadzenie Ogólne Narodów Zjednoczonych, rozporządzenie Rady Ministrów z dnia 13 września 2011 r. w sprawie wzorów formularzy, procedur oraz interwencji w przypadku podejrzenia przemocy w rodzinie, czyli „Niebieskiej Karty”.

Różne formy zabezpieczenia praw dziecka gwarantuje osiem innych, równorzędnych ustaw: 1) Kodeks rodzinny i opiekuńczy z dnia 25 lutego 1964 - porządkuje zagadnienia dotyczące sprawowania władzy rodzicielskiej; 2) Kodeks cywilny $z$ dnia 23 kwietnia 1964 r. - reguluje kwestie prawne dotyczące dóbr osobistych dziecka; 3) Kodeks postepowania cywilnego z dnia 17 listopada 1964 - normalizuje dylematy dotyczące interwencji w sytuacji zagrożenia dziecka; 4) Ustawa o postępowaniu w sprawie nieletnich z dnia 26 października 1982 r. - dotyczy kwestii popełnienia czynu karalnego przez osobę nieletnią oraz pojawienia się przejawów demoralizacji; 5) Ustawa o prawie autorskim i prawach pokrewnych z dnia 4 lutego 1994 r. - rozstrzyga wszystkie kwestie dotyczące wizerunku dziecka; 6. Kodeks karny z dnia 6 czerwca 1997 r. - w rozdziałach dotyczących przestępstw na szkodę nieletniego; 7) Ustawa o ochronie danych osobowych z dnia 29 sierpnia $1997 \mathrm{r}$. - zapewnia ona ochronę danych osobowych dziecka i sposób reagowania $\mathrm{w}$ razie ich naruszenia; 8) Ustawa o przeciwdziałaniu przemocy $\mathrm{w}$ rodzinie z dnia 20 września 2005 r. - określa formy reagowania na podejrzenie przemocy w rodzinie. 
Wszystkie te akty prawne nie zagwarantują bezpieczeństwa dzieciom same z siebie. Najważniejsza jest autentyczna troska o dobro dziecka ze strony osób dorosłych, rodziców, opiekunów, nauczycieli i wychowawców, przejawiająca się w życzliwej obecności i budowaniu relacji opartych na szacunku i zaufaniu oraz w mądrym towarzyszeniu dziecku w jego codziennych zmaganiach. Jak twierdzi Maria Beisert, badająca sprawców nadużyć seksualnych wobec dzieci:

badania udowodniły, że czynnik socjalizacji rodzinnej, czyli relacji dziecka i rodzica i sposobu odnoszenia się rodzica wobec dziecka jest czynnikiem bardzo ważnym dla przyszłego sprawcy. Chodzi tu o takie proste sprawy, jak postawa rodzica wobec dziecka, szacunek wobec dziecka, chęć dawania mu wspierających go wskazówek, konsekwencja, miłość i tolerancja w dawaniu dziecku autonomii. Są to kwestie podstawowe, które potem powodują, że dziecko potrafi stworzyć właściwy związek, także miłosny i seksualny. Jeśli dziecko nie wynosi takiej bazy $\mathrm{z}$ relacji z rodzicami, to nie potrafi stworzyć związku równościowego, tylko tworzy związki niedojrzałe (Klasa, 2011).

Badania Marii Beisert co do genezy pedofilii występującej u sprawców obcych (w tę kategorię wpisują się pedofile działający w Internecie) doprowadziły do kilku istotnych ustaleń. Kluczową rolę w rozwoju patologii odegrały pozabezpieczne style przywiązania dzieci i negatywne postawy rodziców wobec nich. W dorosłym życiu sprawcy

potrzebowali osoby, która nie budzi lęku, nie stawia nadmiernych wymagań i nie odrzuca mężczyzny, co wprost było wynikiem niewłaściwych postaw matek sprawców. Lęk przed obrazem kobiety niekonsekwentnej, nietolerancyjnej i nieakceptującej, skutecznie kierował uwagę ku osobom zależnym, kochającym i słabym. A takie cechy posiada dziecko lub ogólniej osoba niedorosła (Beisert, 2011, s. 165).

W rozmowie z Katarzyną Klasą (2011) badaczka zwraca uwagę na fakt, że większość badanych przez nią osadzonych za nadużycia wobec dzieci wychowywała się bez ojca, nie miała męskiego wzorca zachowań. W przypadku rodzin pełnych

wpływy ojca pośrednio odpowiadały za ukształtowanie się patologicznego, przemocowego wzorca reakcji seksualnej, a wpływy matki bezpośrednio go wzmocniły (Beisert, 2011, s. 166).

Biorąc pod uwagę kryzys rodziny, seksualizację kultury i możliwości nadużyć, jakie stwarza Internet, trzeba uznać, że nasz świat przestał być bezpiecznym miejscem. Kwestia bezpieczeństwa i zapewnienia właściwych warunków rozwoju dzieciom i młodzieży staje się pedagogicznym wyzwaniem. 


\section{BIBLIOGRAFIA}

Adamski, A. (2003). Karnoprawna ochrona dziecka w Sieci. Internet. Prokuratura i Prawo, 9, $59-75$.

Andrzejewska, A., Bednarek, J. (2014). Pedofilia w Sieci. W: Zagrożenia cyberprzestrzeni. Kompleksowy program dla pracowników służb społecznych. Warszawa: Wydawnictwo WSP.

Beisert, M. (2011). Udział środowiska rodzinnego w procesie rozwoju pedofilii. Roczniki Socjologii Rodziny, t. XXI. Poznań: Wydawnictwo UAM.

Beisert, M. (2012). Pedofilia. Geneza i mechanizm działania. Gdańsk: GWP.

Beverly, J. (2003). Leczenie dzieci po urazach psychicznych. Warszawa: PARPA.

Burgess, A.W., Hartman, C.R. (1987). Child Abuse Aspects of Child Pornography. Psychiatric Annals, t. 17, 4.

Carson, R.C., Butcher, J.N., Mineka, S. (2003). Psychologia zaburzeń. T. 2. Gdańsk: GWP.

Dąbrowska, M. (2018). Grooming - wybrane aspekty prawnokarne i kryminologiczne. Pozyskano z: https://brpd.gov.pl/sites/default/files/grooming___wybrane_aspekty_prawnokarne_ i_kryminologiczne_-_marta_dabrowska_ebook.pdf, [data dostępu: 22.12.2018].

DW, J.K. (2018). Pedofilia: codziennie 36 dzieci ofiara przestępstw seksualnych. Pozyskano z: https://www.rp.pl/Prawo-karne/307229997-Pedofilia-codziennie-36-dzieci-ofiara-przestepstw-seksualnych.html.

Dzieci jako ofiary krzywdzenia. Raport z badań. (1998). Warszawa: Fundacja Dzieci Niczyje.

Dziennik Ustaw 1997.78.483.

Dziennik Ustaw 1997.88.553 z późn. zm.

Dziennik Ustaw 2005.180.1493 z późn. zm.

Dziennik Ustaw 2006.90.631, t.j. z późn. zm.

Dziennik Ustaw 2011.209.1245.

Dziennik Ustaw 2014.101, t.j. z późn. zm.

Dziennik Ustaw 2014.1182, t.j. z późn. zm.

Dziennik Ustaw 2014.121, t.j.

Dziennik Ustaw 2015.583, t.j.

Dziennik Ustaw 1991.120.526 z późn. zm.

Dziennik Ustaw. 2014.382, t.j.

Freund, K. (1981). Assessment of pedophilia. W: M. Cook, K. Howells (red.), Adult Sexual Interest in Children, (s. 139-179). London: Academic Press.

Freund, K., Watson, R., Dickey, R. (1990). Does Sexual Abuse in Childhood Cause Pedophilia: An Exploratory Study. Archives of Sexual Behavior, t. 19, 6. Pozyskano z: https://link.springer.com/article/10.1007/BFo1542465, [data dostępu: 16.01.2019].

Hołyst, B. (2007). Kryminologia. Warszawa: PWN.

Imieliński, K. (1990). Seksiatria. T. 2. Warszawa: PWN.

Jędrzejczak, A. (2007). Zasady udostępniania treści pornograficznych w Internecie. Pozyskano z: https://www.eporady24.pl/pornografia_w_internecie,artykuly,6,80,137.html, [data dostępu: 13.01.2019].

Klasa, K. (2011). Wywiad z profesor Marią Beisert. Psychiatria i Psychoterapia, t. 7, 4, 4-14.

Kluczyńska, S. (2002). Przemoc seksualna wobec dzieci. Niebieska Linia, 2.

Kobyłecka, M. (2009). Rola relacji jako pozytywnego zasobu w terapii dzieci - ofiar wykorzystania seksualnego. Dziecko Krzywdzone, 4 (29), 87-95.

Konwencja Rady Europy o ochronie dzieci przed seksualnym wykorzystywaniem i niegodziwym traktowaniem w celach seksualnych, przyjęta przez Komitet Ministrów w dniu 12 lipca 2007 r., w trakcie posiedzenia Zastępców Ministrów nr 1002.

Lew-Starowicz, Z. (2000). Seksuologia sądowa. Warszawa: PZWL.

Lew-Starowicz, Z. (2003). Seks w Sieci i nie tylko. Kraków: Krakowskie Wydawnictwo Medyczne. 
Lim, L.L. (1998). The Sex Sector. The Economic and Social Bases of Prostitution in Southeast Asia. Geneva: International Labour Office.

Polak, Z., Różycka, M., Marańda, M., Szeląg, M. (2013). Zagrożenia internetowe. Wybrane zjawiska. Pozyskano z: https://akademia.nask.pl/publikacje/Zagr-intern.pdf, [data dostępu: 21.01.2019].

Pospiszyl, I. (2008). Patologie społeczne. Warszawa: Wydawnictwo Naukowe PWN.

Pospiszyl, K. (2005) Pedofilia. W: Encyklopedia pedagogiczna XXI wieku. Warszawa: Wydawnictwo Akademickie Żak.

Protokół fakultatywny do Konwencji o prawach dziecka w sprawie handlu dziećmi, dziecięcej prostytucji i dziecięcej pornografii, przyjęty w dniu 25 maja 2000 r., w Nowym Jorku.

Sajkowska, M. (2002). Dzieci wykorzystywane seksualnie. Polskie badania. Pozyskano z: http:// www.psychologia.edu.pl/czytelnia/131-przemoc/1467-dzieci-wykorzystywane-seksualniepolskie-badania-monika-sajkowska.html, [data dostępu: 19.01.2019].

Tanner, J.M., Davies, P.S. (1985). Clinical longitudinal standards for height and height velocity for North American children. J Pediatr, 107, 317-32.

Waglowski, P. (2002). Cyberpornografia dziecięca. Pozyskano z: http://prawo.vagla.pl/node/ 5425, [data dostępu: 13.01.2019].

Wątor, J. (2018). Pedofile w sieci. Pozyskano z: http://wyborcza.pl/7,156282,23141064,pedofile-wsieci-14-tys-zgloszen-w-zeszlym-roku-w-polsce.html, [data dostępu: 19.01.2019].

\section{SUMMARY}

\section{Sexual violence against children in cyberspace}

The Internet has created many new possibilities for child abuse perpetrators. Phenomena like child seduction and pedophilia, child pornography and child prostitution are escalating. Post sexual abuse trauma from childhood has severe consequences in adult life. The crucial question is, how to ensure safety of the Internet youngest users?

KEYWORDS: pedophilia, children, Internet 